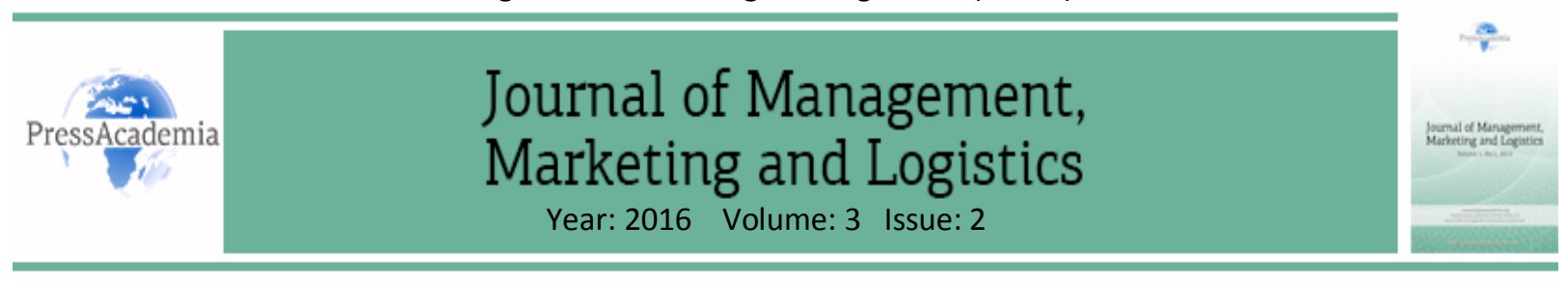

\title{
INNOVATION FACTORS IN SERVICE INDUSTRY AND KNOWLEDGE BASED ECONOMY
}

\section{DOI: 10.17261/Pressacademia.2016219942}

\author{
Ebru Beyza Bayarcelik ${ }^{1}$, Fulya Tasel ${ }^{2}$, Sinan Apak $^{3}$ \\ ${ }^{1}$ Gelişim University, ebbayarcelik@gelisim.edu.tr \\ ${ }^{2}$ Maltepe University, fulyatasel@maltepe.edu.tr \\ ${ }^{3}$ Maltepe University, sinanapak@maltepe.edu.tr
}

\begin{abstract}
Innovation has become one of the most important driver of today's service industry, which plays a key role in knowledge-based economy. In literature generally researches have been emphasized on innovation determinants on manufacturing industry and less concentration on service innovation factors. So this study aims to find out innovation decision factors in service industry by using DEMATEL method. The method was used to analyze the causal relationships and prioritize the importance of innovation factors in logistics industry by applying questionnaire to logistics professionals. Research findings show that research and development is the most important criteria for logistics industry, which also affects knowledge-based economy.
\end{abstract}

Keywords: DEMATEL, knowledge based economy, service industry, innovation

JEL Classification: C44, D8, L8, O3

\section{INTRODUCTION}

Knowledge based economies give importance to the role of knowledge and also technology for economic growth. Knowledge is one of the most important factors which supports economic development. Hence there are many factors which has an important contribution of such a development. Some of those factors are technological progress, globalization of the world economy, increased importance of specialized knowledge, increased awareness of the importance of knowledge for country's economic development and creation of new jobs (Kurtic \& Donlagic, 2012).

The significant progress in services industry is an important sign of economic performance of a country. Fuchs (1964) defined the service sector in his study and includes several industries such as finance, insurance, wholesale and retail trade, and real estate, personal services, professional services, business services, and repair services etc... According to Hill, service is "a change in the condition of a person, or a good belonging to some economic unit, which is brought about as a result of the activity of some other economic unit, with the prior agreement of the former person or economic unit" (Hill, 1977). On the other hand, Metcalfe and Miles defined services as the activities which generates changes and make transformations in its form, place or time of availability etc. Therefore service functions can be classified as design, marketing, after-sales, research and development, delivery, maintenance, etc. (Metcalfe \& Miles, 2000). For today's knowledge-based economies, service industries hold an increasingly important role. Logistics industry is one of the important example of the birth and development of a vital new service-based industry, transformed from the business concept of transportation to that of serving the entire logistical needs of customers (Chapman \& Soosay, 2003). This could be seen from the definition of logistics management which is defined by Council of Supply Chain Management Professionals as "logistic management is a part of supply chain management that plans, implements, and controls the efficient, effective forward and reverses flow and storage of goods, services and related information between the point of origin and the point of consumption in order to meet customers' 
requirements" (2012). As a result of globalization of the economy and the increase in competitive pressure, firms have to restructure cost and service advantages by constantly improving logistics performance (Zhao \& Wang, 2010). Because of this, companies have begun to see logistic operations as a significant tool for differentiation in competition, thus forms development of increased competition among logistics firms, which, in turn, has led these firms to obtain significant changes through the supply of innovative logistics products for customers (Mentzer et al., 2004).

The importance of innovation in the services sector and also the contribution of the services sector's to economic growth is increasingly recognized and has led to a number of studies on innovation in services (OECD, 2005). Joseph Schumpeter is among the first economists who used the innovation concept in his studies. He supported that, the fundamental impulse that sets and keeps the capitalist engine in motion comes from the new consumers, goods, the new methods of production or transportation, the new markets, the new forms of industrial organization that capitalist enterprise creation (Schumpeter, 1942). He argued that economic development is driven by innovation through a dynamic process in which new technologies replace the old, a process he labelled "creative destruction". In Schumpeter's view, "radical" innovations create major disruptive changes, whereas "incremental" innovations continuously advance the process of change. Schumpeter proposed a list of five types of innovations; introduction of new products, introduction of new methods of production, opening of new markets, development of new sources of supply for raw materials or other inputs, creation of new market structures in an industry (OECD, 2005). Toivonen and Tuominen indicate that incremental and less tangible improvements are nowadays counted among innovations, and the role of everyday business as an important arena for the creation of innovations has been acknowledged. The output of services makes it difficult to identify a change or improvement in a service than for an industrial product. When directly asked, service companies often cannot tell whether they have produced innovations (Toivonen \& Tuominen, 2009).

While writers made researches on production and service innovation, logistics innovation has not been paid enough attention by researchers. In 2005, Flint and his colleagues mentioned that logistics research has largely ignored innovation. Innovations in services are either ignored, or every service action is accepted as an innovation based upon its unique nature (Flint et al., 2005). Also Wagner (2008) has made investigation in the logistics field over a forty-year-period up to 2008, observing that only six articles had been written on the topic of innovation in logistics, logistic services and the transportation industry. Thereafter Grawe (2009) also points out the limited innovation research in the logistics sector. According to Flint et al. (2005) logistics innovation "refers to any logistics-related service that is seen as new and helpful to a particular focal audience". It could be very basic to very complex and can be applied to internal operations or services with business partners (Flint et al., 2005). On the other hand, Busse and Wallenburg (2011) claimed that knowledge on a typical innovation development process also applies to developing logistics innovation. There is a general agreement about developing logistics innovations which is a dynamic process that develops overtime and requires firms to engage in different activities across different stages, like idea generation, concept development, business analysis, and implementation stage (Pedrosa et al., 2014). The innovation of logistics services may facilitate in developing strong relationships with customers, creating disincentives for competition, enhancing customer loyalty, adjusting costs and executing market activities more efficiently (Burmaoğlu et. al., 2015). So the purpose of this paper is to examine the prioritizing factors that affecting the innovation in logistics industry in Turkey.

A structured analysis tool such as the decision making trial and evaluation laboratory (DEMATEL) method can help structure complicated causal relationships through matrices or graphs which portray relationships between factors, a cognitive mapping of the factors. Many researchers have adopted several components or multiple dimensions to determine important criteria for innovation factors to put forward by using decision making technique DEMATEL; such as Zandhessami et al. (2012) overviewed the major approaches of technology innovation; Chang and Tzeng (2010) presented the influence as innovation performance on knowledge management capabilities of high-tech industry; Abbasi et al. (2013) considered the most influencing criteria that can play a more significant role in achievements of risks evaluation of knowledge-based networks. This method is advantageous in revealing the relationships among factors and prioritizing factors based on the type of relationships and severity of their effects on other factors. However it is difficult to describe the 
uncertain relationships. The survey was taken among 48 logistics professionals from specific sector managers. When the key criteria were found by extensive literature survey, the questionnaire developed for applying decision-making trial and evaluation laboratory (DEMATEL) method was issued to the managers of logistics companies to first prioritize the importance of these criteria and then construct the causal relations among the criteria. In doing so, the key success factors for improving the overall affect can be identified and the improvement can be made by observing the causal relationships of these key success factors.

In light of the established general framework, the study has been structured as follows: In the second section, knowledge economy has been reviewed and determinates of logistic innovation has been considered briefly; In the third section, data and the variables used in the process, the stages of the analysis and the findings have been presented by DEMATEL method to evaluate the criteria used for logistic innovation which is described in Section 2; and finally, in the last section, key logistic innovation criteria are put forward, in light of the acquired data.

\section{THEORETICAL FRAMEWORK AND HYPOTHESIS DEVELOPMENT}

Knowledge is major factor in the flow of material, information and service in logistic industry (Chapman and et al, 2003). Thus it is one of the most important organizational resources that have been impact on innovation which is investigated by the knowledge-based view in literature. Knowledge that needed to develop innovation is much more than to reach individual organizations, focus is interaction between internal and external sources of knowledge that come from different parts such as employees, consumers and suppliers chaos. Firms need effective knowledge management process to transfer data and information to knowledge that needed for innovation process. Chapman and his friends claimed that knowledge networks in logistic services allows firms to create, share and use strategic knowledge to response consumers changing wants and needs like, transport and network management, multinational and multi-site inventory control, multi-cultural facility location management (Chapman and et al, 2003).

Grawe (2009) developed a model of logistics innovation which is based on previous studies in the logistics literature. According to his study, organizational and environmental factors are two main antecedent for logistic innovation. In addition there are many studies which have examined organizational resources and influence that they have on logistic innovation such as Chapman et al.(2003), Autry and Griffis (2008), Hakansson and Persson (2004). In this study based on the logistics innovation literature, research and development (R\&D), technology, organizational learning, human capital and education, governmental focus, infrastructure availability factors are examined as antecedent criteria for logistic innovation.

\section{Research and Development (R\&D)}

$R \& D$ activities have considered as important key factor that increases knowledge economy through innovation. The outcome of the R\&D activities easily enhance the diffusion and flow of knowledge which support the country's national innovation systems (Fang, et al. 2002). According to OECD, "Research and experimental development (R\&D) comprise creative work undertaken on a systematic basis in order to increase the stock of knowledge, including knowledge of man, culture and society, and the use of this stock of knowledge to devise new applications" (OECD,1993). Besides, service innovations are different from production innovation that comes from combination of formal and informal activities and organizational changes, rather than internal technology developments (Sundbo 2009; Elche-Hotelano, 2011). Hence, Research and Development investment increases the probability of satisfying a higher standard of technology in firms and regions, which would allow them to introduce new and superior products and/or processes, resulting in higher levels of income and growth (Bayarçelik and Taşel, 2007). On the other hand studies, which are analyzing the relationship between R\&D and economic growth, found that there is a strong positive relation among R\&D and economic growth (Inekwe, 2014; Gocer, 2013;Wang, et al. 2013; Gülmez, 2012). As well Güloğlu and his colleagues (2012) investigate the causality relation between R\&D expenditure, innovation and economic development in 13 high-income OECD economies. Their research results support that all relations between $R \& D$, innovation and economic growth are positively significant.

Technology is one of the production factors in economic system. Generally it is referred as machinery and equipment as computers and software, telecommunications and inventions designed to improve production 
(Boone \& Kurtz, 2011). Under today's economic conditions technology has been considered as greater significance in services industry as well as productivity in manufacturing (Bitner, Brown and Meuter, 2000; Howells and Tether, 2004). Technology enables service firms to improve service efficiency and effectiveness. And also it plays an important and critical role in the success of companies because information developed from technological innovations that result to generate new products, to improve service efficiency and effectiveness and to remain competitive (Lin, 2008). Information technology consists of the devices or infrastructures like hardware, software, telecommunications, database management, and other technologies, it uses to store data and make them available form of information for organizational decision making. In logistics industry accurate and up-to date information is essential for effective operation so correct use of information and computer technology (ICT) significant source of competitive advantage (Chapman and et al, 2003). At this point, Hazen and Byrd is identified a logistics information technology (LIT) innovation as an "IT application that is perceived as new to the organization of adoption that is used for planning, implementing, and/or controlling procedures for the transportation and storage of goods and services from the point of origin to the point of consumption" (Hazen, 2012). Moreover, technological innovations in the logistics industry can be classified as data acquisition technologies, information technologies, warehousing technologies and transportation technologies (Lin, 2008).

\section{Organizational Learning}

Organizational factors are important as contextual factors on influencing organizational innovation. In research's, scholars are become more concerned on capabilities like organizational innovation that are already embedded in firms. Besides innovation performance, success is closely related with implementing creative ideas within the organization by organizational learning. According to Arago'n and his colleagues, organizational learning is "a collective capability based on experiential and cognitive processes and involving knowledge acquisition, knowledge sharing, and knowledge utilization". Concurrently organizational learning creates organizational climate that values experimentation and risk taking, applies new knowledge \& ideas, tolerates mistakes and failures, rewards nontraditional thinking and increases ability to understand and apply them (Arago'n-Correa et al.,2007). The processes of learning at organizational level involve key components that support knowledge productivity processes, which include searching for information, assimilating, developing and creating new knowledge on products, processes, and services (Günsel et al , 2011). Previous studies proposed that organizational learning influences on organizational performance (McKee, 2005; Wheelwright and Clark, 1992; Hult et al., 2004; Alegre and Chiva, 2008; Flint,2005, 2008). McKee (2005), suggested that product innovation as an organizational learning and he added that routing the organization towards learning supports innovation effectiveness and efficiency. Hult and his friends (2004) proposed that if a firm has been qualified as an innovative, management must build and encourage the organizational climate and systems that embody a clear learning orientation. On the other hand Panayides and So (2005) study's which is investigating logistic innovation, showed that organizational learning mediates the relationship between relationship orientation and logistics innovation. Also Flint's (2008) found out the relationship between knowledge and logistics innovation as they pointed out a direct positive relationship between supply chain learning and logistics innovation.

\section{Human Capital and Education}

According to knowledge based management, one of the most important resource for innovation is individual knowledge stock of its employees. So human capital defines as knowledge resources that consist of skills, experience, expertise, ideas, knowledge, competencies, abilities and values of employees inside organization (Bontis ,2001; Youndt et al, 2004). And also Hudson (1993) added that combination of genetic heritance, education, experience, attitude about life and business can also shaped the human capital of organizations. Human capital is both supportive and essential for innovation performance because employee's knowledge, expertise and competencies are vital in today's complex and dynamic competitive environments (Hsu and Wang, 2012; Subramaniam and Youndt, 2005). Organizations which has wide variety of human capital can be more entrepreneur that can proactive to market opportunities, more efficiently and effectively to communicate with other parties, more rapid to take risks and refuse threats (Han and Lin, 2014). By the way human capital can minimize decision making mistakes so increase innovation performance (Luthans and 
Youssef, 2004). Martín-de-Castro and friends (2011) claimed that "High-quality talents with good education and sophisticated skills can develop increased cognitive abilities, leading to more productive and efficient activity to improve their job performance, which helps enterprises have better entrepreneurial judgment, run business more smoothly and ultimately improve the firm's innovative performance" (Martín-de-Castro et al., 2011).

\section{Govermental Focus}

The governmental factors such as regulations, the legal environment, the efficiency or the effectiveness of the government (public utilities, public transportation, security, education and health...) has an important effect on innovation (Jiao, Koo, \& Cui, 2015). Also the government policies can affect the potential of firm innovation and also can contribute or prevent the firm's innovation and economic welfare (Guan \& Yam, 2015). An et al. (2009) discovered that the government's R\&D subsidies can encourage innovation and can be used as a key policy. While government policies and regulations can promote significant fundamental changes in product and process technology, which can also benefit the industrial innovators. But if it is not carefully managed there may be harmful effects on innovation (Patanakul \& Pinto, 2014). Patanakul and Pinto (2014) suggested that government should have innovation policies that act in combination in both direct and supporting roles for promoting and sustaining innovations. The government should maintain a set of innovation policies that defines clear targets that can boost firms toward technological changes. There may be different types of policies that governments should take. Patanakul and Pinto (2014) defines those policies that assist the firms in developing and improving their technical capacity, the policies that emphasize the development and improvement of infrastructures and business platforms, policies that promote a quality workforce, and policies that create favorable business environments. Properly developing these policies should thus encourage firms to develop their strategy for innovation. The portfolio of policies can also help governments successfully support and sustain innovation. Some policies may have a long-term effect while some policies may have a short-term effect (Patanakul \& Pinto, 2014). Kim et. al. (2012) supported that patent protection is an important determinant of innovation and that patentable innovations contribute to economic growth.

\section{Infrastructure Availability}

Infrastructure is one of the important factor which generate opportunities and arises from physical assets, human capital, and general technical structure. The requirements for infrastructures, incentives, and institutions to allow building the necessary distributed knowledge bases for the learning society (Conceicao, Heitor, \& Francisco, 2003). Conceicao et al. indicates that, for knowledge based economies infrastructure for education called as knowledge infrastructure is also important. The education system, research and teaching activities are important indicators of infrastructure for education. Another important factor for innovation in knowledge-based economies is technological infrastructure, which consists of science, engineering, and technical knowledge available to industry (Conceicao, Heitor, \& Francisco, 2003).

\section{Intellectual Property Rights}

Intellectual property rights have an important effect on research and development activities. One of the reasons for this is the growing importance of knowledge management in business. Innovation processes depend strongly on knowledge and profiting from knowledge is a vital aspect of innovation management, especially in high tech firms. Intellectual property rights are used to create revenue, to keep the firm's competitive position and to signal competitiveness (Candelin-Palmqvist et. al., 2012). Woo et al. indicates that both in theory and also with the empirical results, strong intellectual property rights stimulates technological innovation by encouraging the inventors who drive economic growth (Woo, Jang, \& Kim, 2015). Woo and his friends (2015) indicates that the difference in the technological composition of specific industries leads to different incentives for protecting intellectual assets through patents. In viewing the firm as a nexus of contracts, the property rights of contracting parties and the security of those property rights clearly influence decision making, and thus firm-level outcomes. R\&D investment is an intangible asset whose value is highly sensitive to the threat of unlawful taking. That is, absent strong property rights protections, firms will be unable to turn on their investment. On the other hand, when intellectual property rights protections are weak, a firm's ability to obtain the acquirements from investment is limited, and this reduces the incentive to invest in innovation (Fan et. al., 2013). 


\section{DATA AND METHODOLOGY}

Decision-making trial and evaluation laboratory (DEMATEL) method applied to study and resolve complicated and intertwined problems by Fontela nad Gabus (1974). The DEMATEL method has been successfully applied in many situations, such as marketing strategies, R\&D project, e-learning evaluation, managers' competencies, control systems and airline safety problems (Lin and Wu 2008). DEMATEL method could improve understanding of the specific problematic, the cluster of intertwined problems, and contribute to identification of workable solutions by a hierarchical structure (Govindan and Chaudhuri, 2016). Unlike the traditional techniques such as analytic hierarchy process with the assumption that elements are independent, this method, one of the structural modeling techniques, can identify the interdependence among the elements of a system through a causal diagram (Awasthi and Govindan, 2016).

Different than the traditional techniques such as analytic hierarchy process with the assumption that elements are independent, this method, one of the structural modeling techniques, can identify the interdependence among the elements of a system through a causal diagram (Lee et al., 2013). The causal diagram uses digraphs rather than directionless graphs to portray the basic concept of contextual relationships and the strengths of influence among the elements (Ren et al., 2013).

The procedure of DEMATEL method is summarized as follows based on Tzeng et al. (2007):

Step 1

Compute the average matrix. Each respondent was asked to evaluate the direct influence between any two factors by an integer score ranging from $0,1,2,3$, and 4, representing "no influence", "low influence", "medium influence", and "high influence", respectively. The notation of $x_{i j}$ indicates the degree to which the respondent believes factor $i$ affects factor $\mathrm{j}$. For $\mathrm{i}=\mathrm{j}$, the diagonal elements are set to zero. For each respondent, an $n \times n$ non-negative matrix can be established as;

$X^{k}=\left[x_{i j}^{k}\right]$, where $\mathrm{k}$ is the number of respondents with $1 \leqslant \mathrm{k} \leqslant \mathrm{H}$, and $\mathrm{n}$ is the number of factors. Thus, $X^{1}, X^{2}$, $X^{3}, \ldots, X^{H}$ are the matrices from $H$ respondents. To incorporate all opinions from $H$ respondents, the average matrix $A=\left[a_{i j}\right]$ can be constructed as follows:

$$
a_{i j}=\frac{1}{H} \sum_{k=1}^{H} x_{i j}^{k}
$$

Step 2

Calculate the normalized initial direct-relation matrix. Normalize initial direct-relation matrix $D$ by $D=A \times S$, where $S=\frac{1}{\max _{0 \leq x \leq 1} \sum_{j=1}^{n} a_{i j}}$. Each element in matrix $D$ falls between zero and one.

Step 3

Calculate the total relation matrix. The total relation matrix $T$ is defined as $T=D(I-D)-1$, where $l$ is the identity matrix. Define $r$ and $c$ be $n \times 1$ and $1 \times n$ vectors representing the sum of rows and sum of columns of the total relation matrix $T$, respectively. Suppose $r_{i}$ be the sum of $i^{\text {th }}$ row in matrix $T$, then $r_{i}$ summarizes both direct and indirect effects given by factor $i$ to the other factors. If $c_{j}$ denotes the sum of $j^{\text {th }}$ column in matrix $T$, then $c_{j}$ shows both direct and indirect effects by factor $\mathrm{j}$ from the other factors. When $j=i$, the sum $\left(r_{i}+c_{j}\right)$ shows the total effects given and received by factor $i$. That is, $\left(r_{i}+c_{j}\right)$ indicates the degree of importance that factor $i$ plays in the entire system. On the contrary, the difference $\left(r_{i}-c_{j}\right)$ depicts the net effect that factor $i$ contributes to the system. Specifically, if $\left(r_{i}-c_{j}\right)$ is positive, factor $i$ is a net cause, while factor $I$ is a net receiver or result if $\left(r_{i}-c_{j}\right)$ is negative.

Step 4

Set up a threshold value to obtain the digraph. Since matrix T provides information on how one factor affects another, it is necessary for a decision maker to set up a threshold value to filter out some negligible effects. In doing so, only the effects greater than the threshold value would be chosen and shown in digraph. In this 
study, the threshold value is set up by computing the average of the elements in matrix $T$. The digraph can be acquired by mapping the dataset of $\left(r_{i}+c_{j}, r_{i}-c_{j}\right)$.

\section{APPLICATION}

Seven major criteria were identified including Research \& Development, Information Technology, Intellectual Property Rights, HR \& Education, Organizational Learning, Infrastructure Availability, and Governmental Focus. The computation of using DEMATEL method is based upon these 48 logistician's opinions. The average matrix A can be constructed based on equations:

$T=\left[\begin{array}{lllllll}0.2721 & 0.4652 & 0.3646 & 0.5143 & 0.3470 & 0.4401 & 0.4301 \\ 0.3148 & 0.2203 & 0.2365 & 0.2470 & 0.2167 & 0.1620 & 0.2471 \\ 0.3732 & 0.4750 & 0.2101 & 0.4203 & 0.4489 & 0.4235 & 0.2323 \\ 0.2323 & 0.4161 & 0.2424 & 0.1986 & 0.1872 & 0.2491 & 0.2518 \\ 0.4113 & 0.4549 & 0.2260 & 0.2440 & 0.2011 & 0.2355 & 0.3025 \\ 0.2215 & 0.2227 & 0.1781 & 0.3059 & 0.3423 & 0.1418 & 0.1460 \\ 0.2304 & 0.3744 & 0.1377 & 0.3102 & 0.2868 & 0.1322 & 0.1591\end{array}\right]$

Table 1 depicts the direct and indirect effects of seven criteria. Finally, the threshold value used in Step 4 is to compute the average of the elements in matrix $T$. The digraph of these seven criteria is depicted in Fig. 1.

Table 1:The Sum of Influences Given and Received among These Seven Criteria on Dimensions

\begin{tabular}{|l|l|l|}
\hline \multicolumn{2}{|l|}{ Dimensions } & $r+c$ \\
\hline C1 & Research \& Development & 4.8889 \\
\hline C2 & Information Technology & 4.2831 \\
\hline C3 & Intellectual Property Rights & 4.1786 \\
\hline C4 & HR \& Education & 4.0179 \\
\hline C5 & Organizational Learning & 4.1052 \\
\hline C6 & Infrastructure Availability & 3.3425 \\
\hline C7 & Governmental Focus & 3.4097 \\
\hline
\end{tabular}




\section{Figure 1: The Digraph of Showing Causal Relations among These Seven Criteria.}

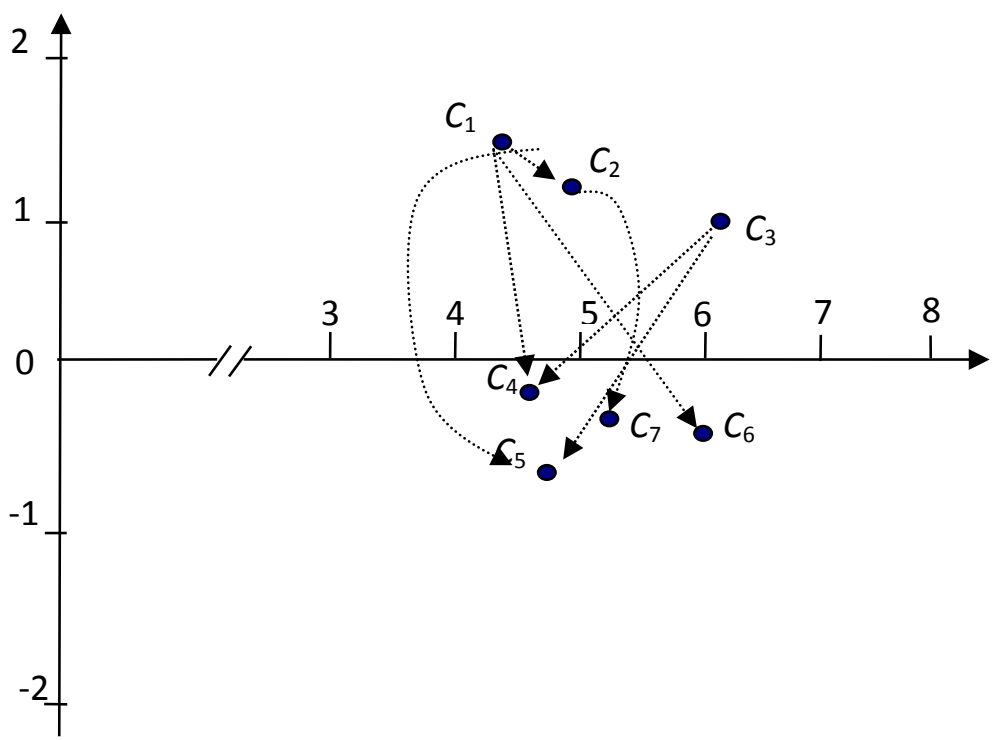

Based on Table 1, the importance of the seven criteria can be prioritized as Research \& Development > Information Technology > Intellectual Property Rights > Organizational Learning > HR \& Education > Governmental Focus $>$ Infrastructure Availability based on $(r+c)$ values, where Research \& Development is the most important criteria with the value of 4.8889 , while Infrastructure Availability is the least important criteria with the value of 3.3425 .

\section{CONCLUSION}

In rapid changing information age, for organizations, using the knowledge effectively and creating value is crucial for survival. Knowledge is a major factor which plays an important role in the flow of material, information and service in logistics industry. In addition to this, innovation is the key factor for renewal of science and technology by using research and development implementations and investments. The other important part of our proposed model is, it might be applied in the various types of decision-making processes and has significantly increased the efficiency of decision-making process to find out the problem.

DEMATEL method helps the decision makers in identifying the casual relationships among criteria. By using this method, the importance of seven criteria can be determined and also the causal relations among the criteria can be constructed. The results reveal that Research \& Development is the most essential criteria of innovation decision for logistics industry. The outcome of the R\&D activities easily enhances the diffusion and flow of knowledge which support the country's national innovation systems (Fang, et al. 2002). Findings are similar with prior studies supporting the idea that R\&D activities is considered as important key factor that increases knowledge economy through innovation (Bayarçelik and Taşel, 2007; Inekwe, 2014; Gocer, 2013; Wang,et al. 2013; Gülmez, 2012; Güloğlu and his colleges, 2012). R\&D investment increases the probability of generating higher level of technology in firms and regions, which would let them to introduce new and better products and/or processes, resulting in higher levels of income and growth. 


\section{REFERENCES}

Akerlof, G.A. 1970, "The Market for "Lemons": Quality Uncertainty and the Market Mechanism", Quarterly Journal of Economics, vol. 84, no. 3, pp. 488-500.

Alessandri, T., Cerrato, D. \& Depperu, D. 2014, "Organizational slack, experience, and acquisition behavior across varying economic environments", Management Decision, vol. 56, no. 5, pp. 967-982.

Abbasi, M., R. Hosnavi, and B. Tabrizi, (2013). Application of fuzzy DEMATEL in risks evaluation of knowledge-based networks Journal of Optimization, 2013, 7.

Alegre, J., Chiva, R.(2008), "Assessing the impact of organizational learning capability on product innovation performance: An empirical test", Technovation , 28, 315-326.

Awasthi, A., Govindan, K., 2016. Green supplier development program selection using NGT and VIKOR under fuzzy environment. Comput. Ind. Eng. 91, 100-108.

Arago'n-Correa, J.A. ,Garcl'a-Morales, V.J., Cordo' n-Pozo, E. (2007) Leadership and organizational learning's role on innovation and performance: Lessons from Spain ,Industrial Marketing Management, $36349-359$.

Bayarçelik, E.B., Taşel, F., 2012, "Research and Development: Source of Economic Growth”, Procedia - Social and Behavioral Sciences, Vol.58, 12 October 2012, 695-701. 8th International Strategic Management Conference, June 20-24 2012, Barcelona/Spain.

Bitner, M.J., Brown, S.W. and Meuter, M.L. (2000), 'Technology Infusion in Service Encounters', Journal of the Academy of Marketing Science, 28: 1, pp. 138-149.

Bontis, N., (2001) Assesing Knowledge Assets: A Review of the Models Used to Mesaure Intellectual Capital, International Journal of Management Reviews, 3(1) .

Boone, L. E., Kurtz D.L., 2011, “Contemporary Business” 14th Ed. Wiley and Son.

Burmaoğlu, S., Şeşen, H., Kazançoğlu, Y., (2015). “Determinants of Logistic Sector Innovation Creating Common Value Nodes in Supply Chain", EUL Journal of Social Sciences, 6(2), pp.37-58.

Busse, C., Wallenburg, C.M. (2011) "Innovation management of logistics service providers Foundations, review, and research agenda",International Journal of Physical Distribution \& Logistics Management,(41).2, pp. 187-218.

Candelin-Palmqvist, H., Sanberg, B., Mylly, U. (2012). "Intellectual property rights in innovation management research: A review", Technovation, Vol. 32, pp. 502-512.

Chang, H.-F., Tzeng, G.-H., 2010. A Causal decision making model for knowledge management capabilities to innovation performance in Taiwan's high-tech industry. Journal of Technology Management \& Innovation J. Technol. Manag. Innov. 5(4), 137-146.

Chapman, R.L., Soosay, C. and Kandampully, J., (2003), "Innovation in logistic services and the new business model”, International Journal of Physical Distribution \& Logistics Management, Vol. 33 No. 7, pp. 630-50.

Conceicao, P., Heitor, M. V., \& Francisco, V. (2003). Infrastructures, incentives, and institutions: Fostering distributed knowledge bases for the learning society. Technological Forecasting \& Social Change (70), 583-617.

Elche-Hotelano, D., (2011), "Sources of knowledge, investments and appropriability as determinants of innovation: An empirical study in service firms", Innovation: Management, policy \& Practice (13): 220-235.

Fan, J.P.H., Gillan, S.L., Yu, Xin. (2013), "Innovation or imitation? The role of intellectual property rights protections", Journal of Multinational Financial Management, Vol. 23, pp.208-234.

Fang, S.C., Lin, J.L., Hsiao, L.Y.C., Huang, C.M., Fang, S.R., (2002), "The relationship of foreign R\&D units in Taiwan and the Taiwanese knowledge-flow system", Technovation, (22) 371-383.

Flint, D.J., Larsson, E., Gammelgaard, B. and Mentzer, J.T. (2005) “Logistics Innovation: A Customer ValueOriented Social Process”, Journal of Business Logistics, Vol. 26, No. 1, pp 113-147.

Fontela, E., \& Gabus, A. (1974). DEMATEL, innovative methods, Report no. 2, Structural analysis of the world problematique. Battelle Geneva Research Institute.

Gocer, I.(2013), "Effects of R\&D expenditures on high technology exports, balance of foreign trade and economic growth", Maliye Dergisi, $165,215-240$

Govindan K. and Chaudhuri A. (2016). Interrelationships of risks faced by third party logistics service providers: A DEMATEL based approach Transportation Research Part E: Logistics and Transportation Review, Volume 90, Pages 177-195.

Gülmez, A., Yardımcıoğlu, F.,(2012) "The relationship between R\&D expenditure and economic growth in OECD countries: Panel cointegration and panel causality analyses (1990-2010)". Maliye Journal, 163, 335-353.

Guan, J., \& Yam, R. C. (2015). Effects of government financial incentives on firms' innovation performance in China: Evidences from Beijing in 1990s. Research Policy, 1(44), 273-282. 
Gunsel, A., Siachou E., Acar, A. Z.(2011) Knowledge Management And Learning Capability To Enhance Organizational Innovativeness, Procedia Social and Behavioral Sciences $24,880-888$

Han, Y., Li, D., (2014), "Effects of intellectual capitalon innovative performance, The role of knowledge-based dynamic capability", Management Decision, 53(1) 1,pp. 40-56.

Hazen, B.T., Byrd, T.A. 2012, "Toward creating competitive advantage with logistics information technology", International Journal of Physical Distribution \& Logistics Management, Vol. 42 No. 1,pp. 8-35.

Hill, T. P. (1977, December). On Goods and Services. The Review of Income and Wealth (4) , 23, 315-338.

Howells, J. and Tether, B.S. (2004), Innovation in Services: Issues at Stake and Trends.A Report for DG Enterprise of the European Commission, under contract INNOStudies 2001: Lot 3 (ENTR-C/2001).

Hsu, L.C., Wang, C.H. (2012), "Clarifying the effect of intellectual capital on performance: the mediating role of dynamic capability", British Journal of Management, Vol. 23 No. 2, pp. 179-205.

Hudson W.(1993), Intellectual Capital: How to Build It, Enhance It, Use It. New York: Wiley

Hult, G.T.M., Hurley, R.F., Knight, G.A., (2004). “Innovativeness: its antecedents and impact on business performance”, Industrial Marketing Management (33), 429-438.

Inekwe, J.N. (2014), "The Contribution of R\&D Expenditure to Economic Growth in Developing Economies", Social Indicators Research, DOI: 10.1007/s11205-014-0807-3.

Jiao, H., Koo, C. K., \& Cui, Y. (2015). Legal environment, government effectiveness and firms' innovation in China: Examinin the moderating influence of government ownership. Technological Forecasting \& Social Change(96), 15-24.

Kim, Y.K., Lee, K., Park, W.G., Choo, K. (2012). "Appropriate intellectual property protection and economic growth in countries at different levels of development". Research Policy, Vol. 41, pp. 358-375.

Kurtic, A., \& Donlagic, S. (2012). Determining Key Factors for Knowledge Economy Development in Bosnia and Hercegovina. Management, Knowledge and Learning International Conference.

Lee, H.S., Tzeng, G.H., Yeih, W., Wang, Y.J., Yang, S.C., 2013. Revised DEMATEL: resolving the infeasibility of DEMATEL. Appl. Math. Model. $37(10), 6746-6757$.

Lin, Chieh-Yu(2008),"Determinants of the adoption of technological innovations by logistics service providers in China", International Journal of Technology Management and Sustainable Development, 7 (1) 19-38.

Lin, C. J., Wu, W.W. (2008). A causal analytical method for group decision-making under fuzzyenvironment, Expert Systems with Applications, 34(1), $205-213$.

Luthans, F.,Youssef, C.M. (2004), "Human, social, and now positive psychological capital management: investing in people for competitive advantage", Organizational Dynamics, Vol. 33 No. 2, pp. 143-160.

Martín-de-Castro, G., Delgado-Verde, M., López-Sáez, P. and Navas-López, J.E. (2011), “Towards 'an intellectual capital-based view of the firm': origins and nature", Journal of Business Ethics, Vol. 98 No. 4, pp. 649-662.

McKee, D., (1992). “An organizational learning approach to product innovation”, Journal of Product Innovation Management 9 (3),232-245.

Mentzer J., Myers, M. B., \& Cheung, M. (2004), “Global market segmentation for logistics services”, Industrial Marketing Management, 33 : 15-20.

Metcalfe, j. S., \& Miles, I. (2000). Introduction, Overview and Reprise. J. S. Metcalfe, \& I. Miles içinde, Innovation Systems in the Service Economy: Measurement and Case Study Analysis. Newyork: Springer Science and Business Media, LLC.

OECD. (2005). Oslo Manual: Guidelines for collecting and interpreting innovation data (3rd ed. b.). OECD Publishing.

Panayides, Ph. M. and So, M. (2005), "Logistics service provider-client relationships", Transportation Research E, Vol. 41, No. 3, pp. 179200.

Patanakul, P. and Pinto J. K. (2014), “Examining the roles of government policy on innovation”, Journal of High Technology Management Research, Vol. 24, pp. 97-107.

Pedrosa, A.,Blazevic, V., Jasmand, C., (2015). "Logistics innovation development: a micro-level perspective". International Journal of Physical Distribution \& Logistics Management, 45 (4), pp. 313-332.

Ren, J., Manzardo, A., Toniolo, S., Scipioni, A., 2013. Sustainability of hydrogen supply chain. Part I: Identification of critical criteria and cause-effect analysis for enhancing the sustainability using DEMATEL. Int. J. Hydrogen Energy 38 (33), 14159-14171.

Subramaniam, M., Youndt, M.A. (2005), "The influence of intellectual capital on the types ofinnovative capabilities", Academy of Management Journal, Vol. 48 No. 3, pp. 450-463. 
Sundbo, J. (2009) Innovation in the experience economy: A taxonomy of innovation organisations, The Service Industries Journal 29(4): $431-455$.

Schumpeter, J. A., 1942. Capitalism, Socialism, and Democracy, Harper \& Brothers, New York.

Tzeng, G.H., C.H. Chiang, C.W. Li. (2007). Evaluating intertwined effects in e-learning programs: a novel hybrid MCDM model based on factor analysis and DEMATEL. Expert Syst. Appl., 32 (2007), pp. 1028-1044.

Torun, H. , Çiçekçi, C. ( 2007), "Innovation: is the engine for the economic growth?" Ege University The Faculty of Economics and Administrative Sciences Economics IV, 1-54.

Toivonen, M., Tuominen, T. (2009), "Emergence of Innovations in services”, The Service Industries Journal, Vol. 29, No.7, pp. 887-902.

Wang, D.H.M., Yu, T.H.K, L,H.Q.,(2013) ,"Heterogeneous effect of high-tech industrial R\&D spending on economic growth” Journal of Business Research 66(10):1990-1993•

Wheelwright, S.C., Clark, K.B., (1992). Revolutionizing Product Development-Quantum Leaps in Speed, Efficiency, and Quality. The Free Press, New York.

Woo, S., Jang, P., \& Kim, Y. (2015). Effects of intellectual property rights and patented knowledge in innovation and industry value added: A multinational emprical analysis of different industries. Technovation, 49-63.

Youndt, M.; Subramaniam, M.; Snell, S. A.(2004), "Intellectual capital profiles: An examination of investments and returns", Journal of Management Studies, 41(2), pp. 335-361.

Zhao, D., \& Wang, M. (2010), Research on logistics business outsourcing andlogistics service innovation. Paper presented at the International Conference on Management and Service Science (MASS), Wuhan, China.

Zandhessami, H., Shima Parvinchi, Zeinab Molaei (2012). "Identification and prioritization of technology innovation capability on technology innovation performance". International Journal of Economics and Management Sciences 1, 6, 13-20. 